\title{
〔解 説〕自律移動ロボット要素技術の動向
}

\section{自律移動のロボットにおける知能化技術}

\section{(1) 行 動 プラニング}

柿倉 正 義**

\section{1.はじめに}

自律移動ロボットシステム及びその行動プランニング に関しては, 多くの研究がなされており, 各研究者によ ってその意味するところが若干異る1が，その概要は图 1のようなるのであろらり。この四から言えることは， プラニングの機能は本質的にはそれだけで独立に存在し 得るものではなく，外界に働きかける機能と，外界を認 識する機能と共存することによって初めて存在意義のあ るものになるといらことであり,これらの共通部分とし て知識ベースが存在する.

本特集号においても，若千のニュアンスの相違はある が因 1 の各部に対応した解説がなされている，本稿は，

原稿受付 1987 年 7 月 14 日

* Behavior Planning for Autonomous Moving Robots

** 電子技術総合研究所制御部

†本図は文献 1) 中の困を若干变更したものである.
次項の「ナビダーションとガイダンス」との多少の重複 の存在を許すこととし, 四中の PLANNER, NAVIGATOR, PILOT に対応する部分について解説することと する.

\section{2. 行動計画の澍立}

移動ロボットが移動するのは何らかの目的があっての ことである. その目的を達成するために必要な, 移動口 ボットとしての特徽を活かしての行動計画を立てるのが PLANNER (MISSION PLANNER) の役割である. この行動計画にる様々なレベルが考兄られる．例えば筆 者の居室 (2 階) 飞書類運搬のできる移動ロボットが居 たとして，このロボットに「四書室に行って，ロボット 学会誌の一番最近のものを借りてきて欲しい」と命した としよう，この場合，ロボットとしては，まず 2 階から 8 階の圀書室までどうやって行くかを考光，次汇図書室 でロボット学会誌の置いてある書架を探し最新号を見つ

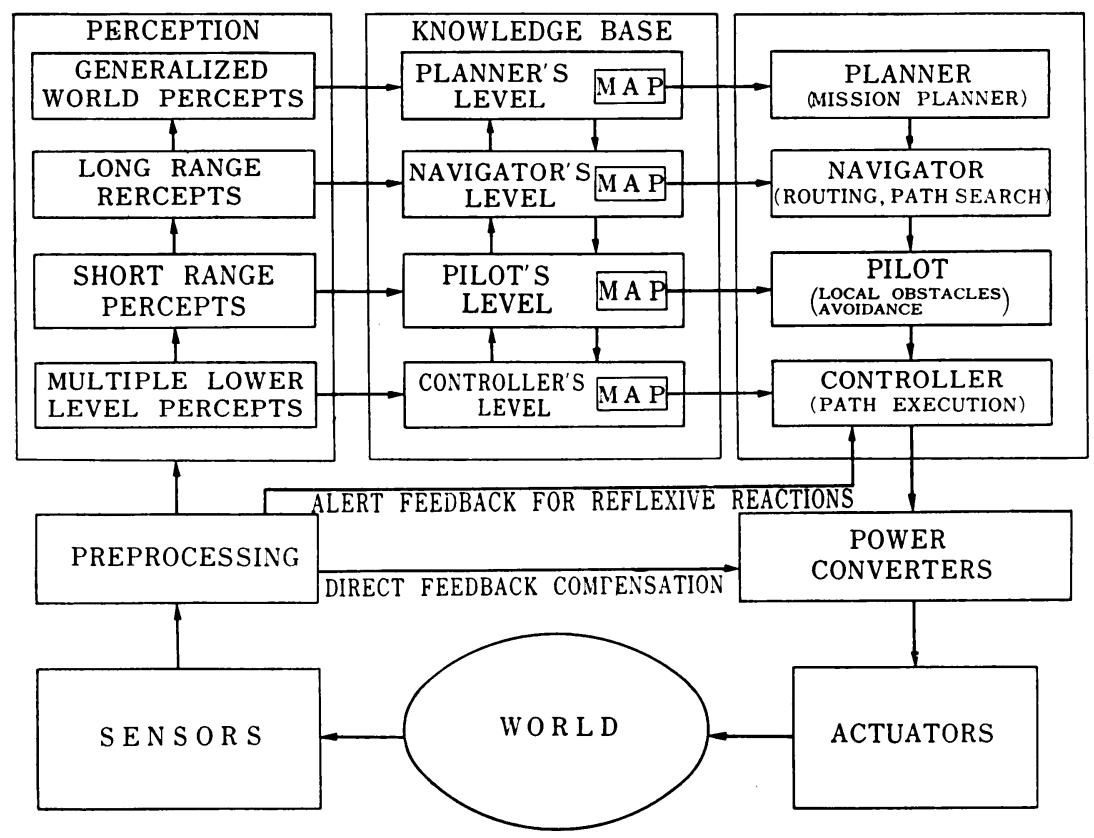

図 1 自律移動ロボットシステムの構成 ${ }^{1)}$ 


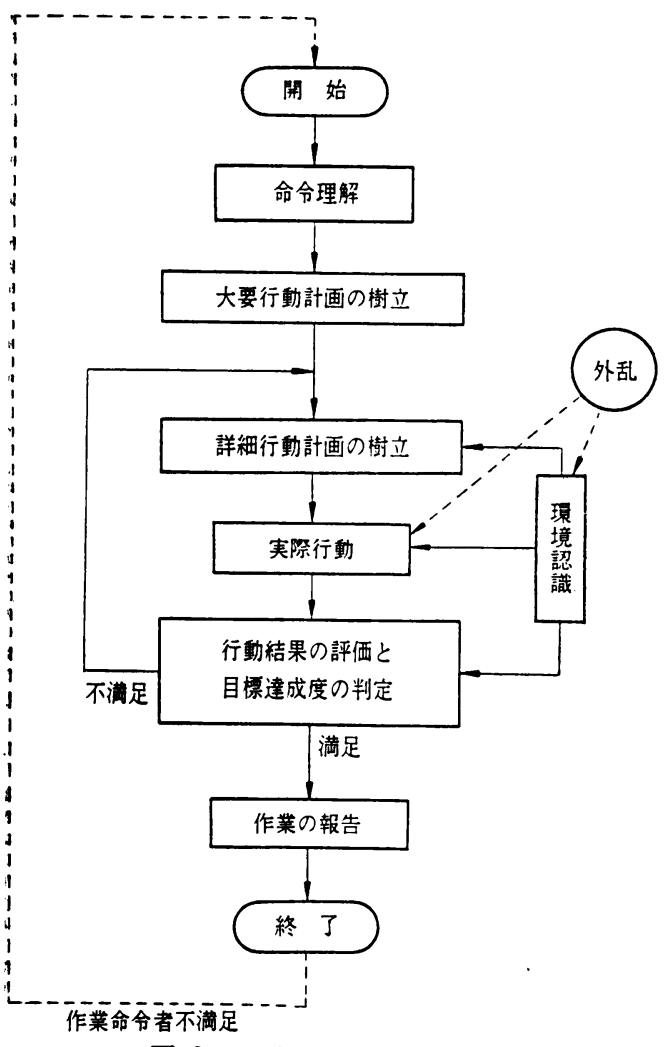

图 2 ロボットの行動の概要

けて, 四書係借用の許可を得て, 次にまた 2 階の居室 まで戻ってくるにはどうすればよいか，といったような 大まかな行動（大要行動）を考皇なければならない，更 に実際の行動（移動）に掛かる前に，8階まで行くため のエレペータに乗るためには, 現在いる部屋から 2 階の エレベータホールまでどうやって行くかという，もう少 乙細かい行動（詳細行動）も考えねばならない。このよ らなロボットの行動の概要は一般的には図2のように表 わされるであろう。

移動ロボットの行動計画に関する研究は, ロボット研 究の初期の段階から行なわれているが, 大要行動計画に 関しては見るべきものがない，それは，大要行動までも 考えて実際に作業するような移動ロボットは, 現状の技 術ではそのシステム構成があまりにも高度かつ複雑にな り過ぎ，実現性に乏しく，結果として机上の空論だけに 終ってしまらからであろら.一方, 詳細行動の一部とし ての行動計画は様々な形で行なわれている. 次項で述べ る経路探索もその 1 つの例であるが, 他の例としては, 別々の所に存在している3つの対象物体を, 移動ロボッ トが「押す」といら操作のみを用いて1箇所に集積する といら問題の解を 1 階の述語論理を用いた問題解決シス テムによって導き，それを用いて実際のロボットシステ
ムを動かすととによって患証するといら研究が，ロボッ 卜研究の初期に行なわれている2． また，これは移動口 ボットではなくマニピュレータによるるのであるが（こ の考え方は移動口ボットにもそのまま啇用できるので引 用した）状能空間の概念を用いて，この種の問題に対す る最適解を求めた研究もある3,4.

\section{3. 経 路 探 索}

因 1 における NAVIGATOR の機能としての routing や path search に対応する日本語は経路探索であろう.

自律形移動ロボットを実現するらえで解決すべき基本 的問題としては, 図 1 の 3 つの部分に対応する, 1) 環 境モデルの作成と更新，2）各種センサの統合的利用,

3) 行動計画の策定がある5) が, 経路探索は3）の行動 計画の策定に拉ける主要な部分である.

経路探索問題とは与えられた環境のもとで，初期点か ら出発して障害物を避けながら目標点に到達する道を見 い出すことであり，場合によっては，その道がある種の 性質を満足すること（最適性）を要求されることあある.

経路探索の問題は移動ロボットとは無関係古くから 行なわれており, 様々なアルゴリズムが問題の状況に応 じて開発されている゚). これらを移動ロボットの観点か ら類別すると，1）環境に関する知識がない場合の探索 法である直観的探索法あるいは試行錯誤的探索法，2) 環境に関する知識が完全な場合の探索法であるグラフ理 論的探索法あるいは数理計画的探索法，3）環境関す る知識が不完全な場合や環境が複雑すぎる場合などの探 索法である発見的探索あるいはハイブリッド探索法，に 分けることができよう. 以下にこれらについて順番に解 説する.

1）直観的探索法あるいは試行錯誤的探索法

この手法は環境に関する情報がほとんどない場合に使 用されるものであり, その経路探索の情況は未知の地域 へ地罒なしで行った人間の探索情況と似たものである. すなわち，経路を探索するロボットは，その出発点にお いては目標点が大体どっちの方向にあるという程度の情 報しか持っておらず，最初はとにかく目標点に近い方向 に動いてみる.そしてその移動の結果により得られた新 しい情報に基づいて，より目標点に近いと思われる方向 に動くことにより経路の探索を継続する. ロボットはこ のような過程を目標点に到達するまで繰り返す. 従って この手法によって得られる経路は必ずしも最短距離等の 最適経路ではないばかりか, 環境の複雑さの度合によっ ては目標点に到達する経路の発見ができない場合がある. この手法に属する最も簡単なるのは触覚情報を利用する ものであり, 目標点に向って進み, 障害物に触ったら, 


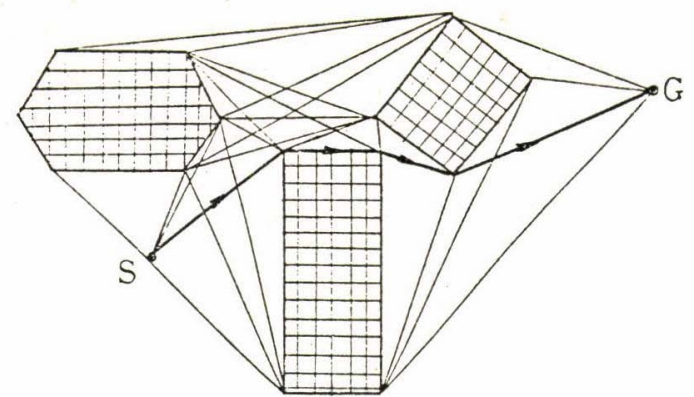

図 3 可視グラフ問題に帰着できる経路探索の例 ${ }^{10)}$

その情報を考慮して次の進むべき方向を決定するといら ものである7)。もら少し進んだものとしては人工視覚を 用いて障害物を検出し，その大きさや斜面の傾斜の情報

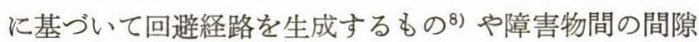
を検出して目標点へ向ら方向の決定を行ならものなどが ある9.

2) グラフ理論的探索法あるいは数理計画的探索法 環境に関する知識が完全である場合，すなわち環境中 に存在する障害物の配置が前もって分っている場合, あ るいは実際にロボットが移動するときに視覚装置などに よって障害物の全体的な配置が決定できれば1）の手法 より効率的な探索手法が適用できる，たと党ば図３に示 されているよらな多角形で表現できる障害物が存在する 環境で, 出発点 $\mathrm{S}$ から目標点 $\mathrm{G}$ まで障害物を避けながら 到達する場合の最短経路は, 図に示されているように明 らかに障害物の頂点を結ぶ直線群の組み合わせの中に存 在する ${ }^{10)}$.このような問題は計算幾何学に打ける可視グ ラフの問題として一般的に扱うことができ, 最短経路は 可視グラフ上で出発点から目標点に到る最短路を求める ことに対応し，ラベリング法などによって，可視グラフ

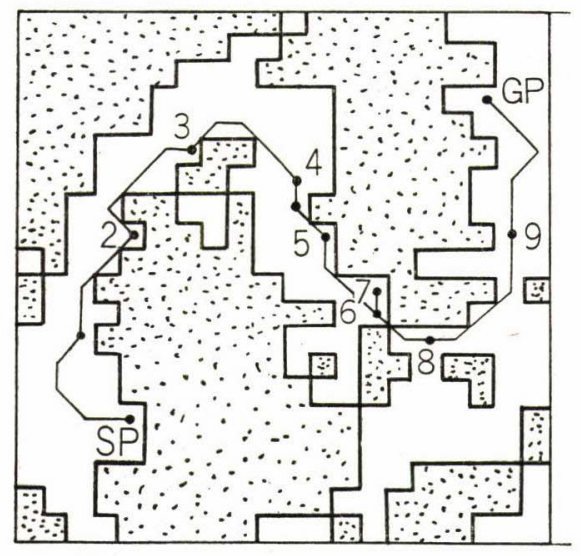

$$
\begin{array}{ll}
\text { : 障害物 } & \text { SP : 出発点 } \\
\text { ：観測点 } & \text { GP : 目標点 }
\end{array}
$$

図 4 観測を併用した経路探索 ${ }^{20)}$
の頂点数を $n$ とすると $O\left(n^{2}\right)$ で計算できることが知ら れている11)。またこのような問題を高速に解くために， ロボットの動き得る空間の構造を超グラフなどを用いて 階層的に記述することにより, 経路探索アルゴリズムの 高速化を図っている研究もある12,13)。ささらに，障害物へ の接触をできるだけ避けるために，各障害物の大きさに よって決定される領域の境界（計算幾何学でいう Voronoi 図) を経路の一部として利用するもの ${ }^{14)}$, 障害物の 有するポテンシャルによって生成されるポテンシャル場 における極小ポテンシャル分布を利用して経路を決定す


れている。

一方，ロボットの移動環境を基盤の目状にブロック化 することによってモデル化し，そのブロック間でのロボ ットの移動を考光ることにより，経路探索を行なう手法 も古くから行なわれている ${ }^{18 \sim 20)}$. この場合には, ブロッ ク間の移動に要するコスト，障害物に対しての衝突によ る損失, 移動環境中に存在する障害物の観測に要する費 用などをパラメータとする評価関数を，動的計画法など の数理計画法の手段を用いて最小化することなどにより, 最適経路を探索することができる. 図 4 亿観測に基づく 障害物の存在情報之， ロボットの有する環境に関する情 報とを併用しながら経路探を行なった例を示す．このよ らなブロック化された環境に拗ける経路探索の精度と効 率を向上させるために，木構造に基づく階層化された空 間記述を用いる方法子提案されている ${ }^{21,22)}$. 図 5 亿 4 分 木を用いた空間記述に基づいて探索された経路の例を示 す. 左下の出発点 Sから右上の目標点 $\mathrm{G}$ に到る経路が斜 線を施されたブロックで示されている. 図から解るよう に障害物の少ない領域では空間記述の階層の上の方のブ ロック，すなわち大きな粗いブロックが用いられ，障害 物の近傍では階層の下の方の小さな細かいブロックが用

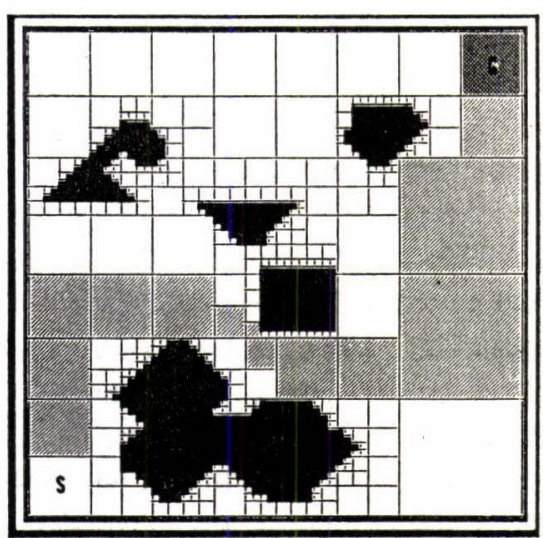

図 54 分木による階層化空間記述を用いた経路探索 ${ }^{22)}$ 


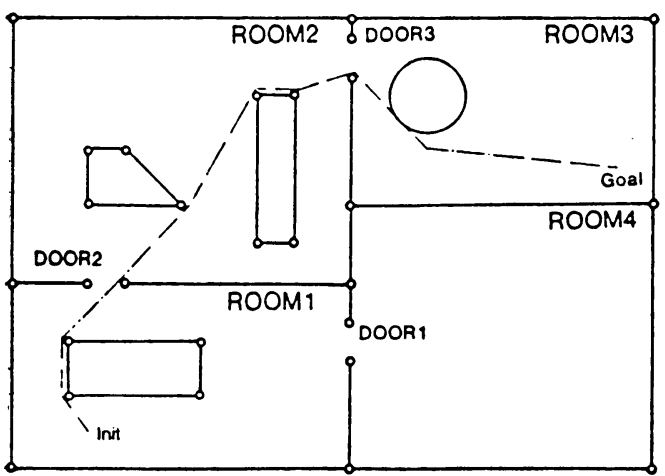

図 6 発見的手法によって探索された経路の例 ${ }^{25)}$

いられている.

このグラフ理論あるいは数理計画法に基づく経路探索 は, どのように環境が複雑であっても, 計量的最適性の みを追求するのであれば, 必ず最適解が理論的には求ま る.しかし，実際には組み合わせの数が膨大となってし まうなどの問題が生じるため何らかの工夫が必要となる ことが多い.

3） 発見的経路探索あるいはハイブリッド経路探索

環境に関する情報が不完全であったり，あるいは環境 があまりにも複雑であったり，さらには経路に要求され る最適性があまりにも強過ぎると，1）の手法では経路 が発見できない，2）の手法では時間が掛かり過ぎたり， 組み合わせ論的爆発が起きる，といった事態が生ずるこ とがある.このような場合には何らかの発見的手法や， いくつかの手法を組み合わせて使用するハイブリッド法 が役に立つことがある.

発見的手法に用いられる発見的知識は, 個々の問題に 依存するものであり，一般的には論じ難い、移動口ボッ トの経路探索で用いられる発見的知識として最も簡単か つよく用いられるものは, (1)現在地点から目標地点へ向 って，障害物に遭遇するまで真直ぐ進む，（2障害物に遭 遇したら，現在地より見える障害物の端点で最も近いも ののところまで行く，(3)障害物に沿って移動する，など であろ ${ }^{23,24)}$ 。図6にこのような発見的知識を利用して 探索された経路の例を示す25).

移動ロボットが, 単に出発点から目標点まで最短距離 あるいは最短時間で到達することを要請されるような問 題に対しては 2) の手法が有効であるが，例えばFAに おけるワークセルに部品を配ってあるくロボットのよう な場合には，このような計量的性質のみたけけでなく位相 的な性質を満足することを要求されることがある゙. こ のような代表的な問題として Chinese Postman Problem と呼ばれるものがある26,27). これは図 7 に示すよ らな街路のネットワークが与えられているとき，郵便屋

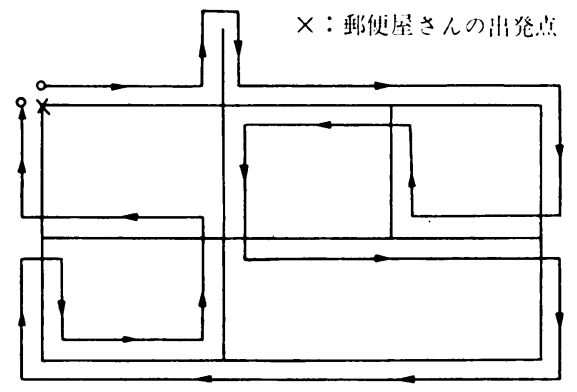

図 7 Chinese Postman Problem の例 ${ }^{26)}$

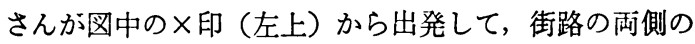
家に郵便物を配達して歩く場合に，重複して通る街路の 長さを最小にする，すなわち全体としての配達経路を最 小にするには，どのような配達経路を採ればよいかとい う問題である. この問題の解法の詳細はここでは述べな い(文献 26 参照）が，基本的にはグラフの奇数次の頂点 に着目するという位相幾何学的な側面と, 重複辺のうち の短い方を採用するといら計量的側面の両方が含まれて いる. 図中の矢印の線分でその解を示す，いまの場合は 1 台の移動体（移動ロボット）に対しての問題であった が, 複数の移動体に対するこのような問題の一般的な解 法は知られていない28).

\section{4. 移動障害物の回避}

ロボット技術の一層の進歩によって複数台の移動ロボ ットが同一環境内で同時に移動するような状況，あるい は人間と共存して移動する状況は十分考え得ることであ る.このような場合にはロボットとロボット，あるいは ロボットと人間との衝突回避の問題を扱わなければなら ない. 図1の PILOT の機能はこのよらな役割を果たす ものである.

従来この種の移動体同士の衝突あるいは遭遇の問題は

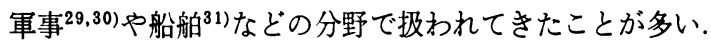
そこでの環境は移動体の大きさに比べて十分広く仮定さ れており, 運動も微分方程式で記述でき, 前記の仮定か ら境界条件等を考虑する必要性も少ない，一方，ロボッ トの場合は，ロボット本体の大きさに比べて環境が狭い ことが多く，必然的に他の固定障害物や壁などの境界条 件をも考慮しなければならない。また，ロボットの運動 そのものも，断続的な動きが多くて微分方程式で記述し にくいなどの問題点もあるため, シミュレーションによ

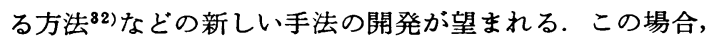
環境に関する情報が完全であれば，ロボットの行動を実 際の行動の前に完全に予測できるので, 衝突回避が可能 となるが，情報が不完全な場合には不確定性が残る。 た，実際には，いま予測された回避行動を実行すること 
によって新しい衝突問題を引き起こす可能性もあること に注意しなければならない。

\section{5. お わりに}

移動ロポットの行動プラニングに関して, 経路探索を 中心にして解説した. 移動ロボットに対する需要は今後 益々増えるものと考光られるが，それに従って移動口ボ ットに要請される行動プラニングの機能も,より複雑な 環境中での経路探索, 複雑かつ高度な評価を満足するよ らな経路の探索, 複数個の移動体や固定障害物等が混在 する環境での経路探索など，より高度な機能が要求され るようになると考学られ, 今後のより一層の研究開発が 望まれる.

\section{参 考 文 献}

1) A. Meystel : Planning in a Hierarchical Nested Autonomous Control System, Proc. Vol.727, Mobile Robot, 42-76 (1986)

2) N. J. Nilsson : A Mobile Automation : An Application of Artificial Intelligence Techniques, Proc. 1 st IJCAI 509-520 (1969)

3) W. R. Ferrell, T. B. Sheridan : Supervisory Control of Remote Manipulation, IEEE Spectrum Oct. 81 88 (1967)

4) D. E. Whitney : State Space Models of Remote Manipulation Tasks, IEEE Trans. Automatic Control, Vol. AC-14, No.6, 617-623 (1969)

5）小林：自律形移動ロボットにおける知識処理, 計測と制 御, 第 26 巻第 2 号, 30-35 (1987)

6）柿倉 : 移動ロボットの経路探索, 日本機械学会誌，第 89 巻第 815 号, 41-46 (1986)

7）松島, 山本, 大仲：触覚つき移動ロボットに関する基礎 的研究 (第 2 報)一その制御之経路探索の基礎的実験一, 精密機械, 第 44 巻第 2 号, 29-32 (1978)

8) L. Y. Lim : A Pathfinding Algorithm for a Myopic Robot, JPL Technical Report 32-1288 (1968)

9) D. F. Cahn and S. R. Phillips : ROBNAV : A RangeBased Robot Navigation and Obstacle Avoidance Algorithm, IEEE Trans. SMC, Vol. SMC-5, No.9, 544-551 (1975)

10) T. Lozano-Pérez and M. A. Wesley : An Algorithm for Planning Collision-Free Paths Among Polyhedral Obstacles, Commun, ACM Vol.22, No.10, 560-570 (1979)

11) 今井：計算幾何学における組合せ的算法, 数理科学 No. 285, 35-39 (1987)

12) L. Gouzènes : Strategies for Solving Collision-free Trajectories Problems for Mobile and Manipulator Robots, Int. Jour. Robotics Research, Vol.3, No. 4, 51-65 (1984)

13) K. D. Rueb and A. K. C. Wong : Structuring Free Space as a Hypergraph for Solving Robot Path Planning and Navigation, IEEE Trans. PAMI, Vol PAMI-9, No.2, 263-273 (1987)

14）比留川, 北村：安全第一アルゴリズムとポテンシャル関 数に基づくマニピニレータの障害物回避法、日本ロボッ 卜学会誌, 第 5 巻第 3 号, 3-11 (1987)
15）奥富, 森：ポテンシャル場を用いたロボットの動作決 定, 日本ロボット学会誌, 第 1 巻第 3 号, 66-72 (1983).

16) R. A. Jarvis : Collision-Free Trajectory Planning Using Distance Transforms, Proc. National Conference and Exhibition on Robotics, Melbourne, 8690 (1984)

17) E. G. Gilbert and D. W. Johnson : Distance Functions and Their Application to Robot Path Planning in the Presence of Obstacles, IEEE Jour, Robotics and Automation, Vol.RA-1, No.1, 21-30 (1985)

18) W. G. Keckler and R. E. Larson : Control of a Robot in a Partially Unknown Environment, Automatica, Vol.6, 469-476 (1970)

19）藤井, 森田, 谷内田 : 知能口ボットの経路探索計画法に ついて, システムと制御, 第 15 巻第 11 号, 68-75 (1971)

20）柿倉, 三島, 長田 : 知能ロボットの記憶構成とそのルー 卜探索への適用, 計測自動制御学会論文集, 第 9 巻第 1 号, 45-50 (1973)

21) E. K. Wong and K. S. Fu : A Hierachical Orthogonal Space Approach to Three-Dimensional Path Planning, IEEE Jour. Robotics and Automation, Vol RA-2, No.1, 42-53 (1986)

22) S. Kambhampati and L. S. Davis : Multiresolution Path Planning for Mobile Robots, IEEE Jour. Robotics and Automation, Vol. RA-2, No.3, 135145 (1986)

23) M. H. E. Larcombe : Mobile Robots for Industrial Use, Industrial Robot, Vol.6, No.2, 70-76 (1979)

24) R. Chattergy: Some Heuristics for the Navigation of a Robot, Int. Jour. Robotics Research, Vol.4, No. 1, 59-66 (1985)

25）市川, 妹尾, 宮田 : 移動機械の自立制御, 計測自動制御 学会論文集, 第 20 巻第 10 号, 87-91 (1984)

26) K. Mei-Ko : Graphic Programming Using Odd or Even Points, Chinese Math. Vol. 1, 273-277 (1962)

27) J. F. Barlow : An Algorithm for the Solution of the Postman's Problem, Compt. Jour. Vol.21, No.1, 86-89 (1978)

28）杮倉, 武野, 向殿：一方通行路の存在する道路網におけ るある種の最適経路問題, 電気学会論文誌 C, 第 98 巻 第 8 号, 15-22 (1978)

29) R. Isaacs : Differential Games, John Wiley, (1965)

30) L. B. Milstein and T. Lazicky : Algorithms to Track a Moving Object, IEEE Proc. Pattern Recognition and Image Processing, 148-152 (1977)

31）喜多: 船舶衝突危険度の解析モデル, 航海, 第 87 号, 27-35 (1986)

32）武野, 柿倉: 移動ロポットの移動障害物に対する衝突回 避問題について, 日本ロボット学会誌, 第 4 巻第 5 号, 33-37 (1986)

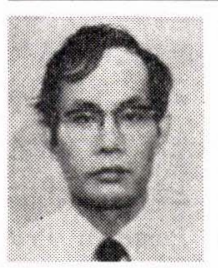

\section{柿倉 正義}

(Masayoshi KAKIKURA)

昭和 40 年, 東京電機大学工学部電子工 学科卒業. 同年, 電気試験所 (現電子技術 総合研究所）入所. 現在, 制御部情報制御 研究室長. 知能ロボットの研究に従事. 昭 和 49-50 年英国エシシンバラ大学人工知能学 科客員研究員. 計測自動制御学会, 電気学会, 電子情報通信学 会, 情報処理学会の会員.
(日本ロボット学会正会員) 